\title{
Unshackling the chains of coloniality: Reimagining decoloniality, Africanisation and Reformation for a non-racial South Africa
}

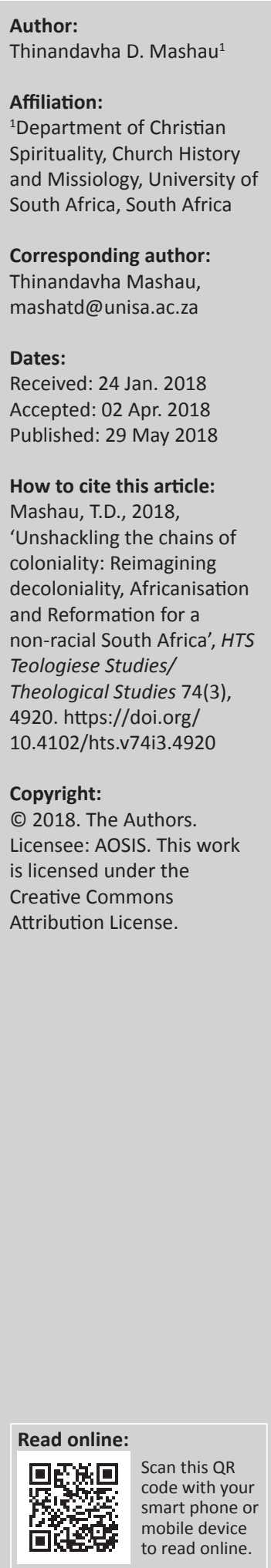

Racial divisions, polarisation and tensions are on the rise in South Africa today. A democratic dream of a rainbow nation remains just a dream with racism continuing to raise its ugly head in the democratic South Africa, to the detriment of the rainbow dream of a united South Africa. This article seeks to probe whether South Africans should continue to sing the song of racial reconciliation in the light of the continued racial tensions and post-colonial and postapartheid legacies and stereotypes that continue to manifest in our private and public spaces. Based on an examination of the decoloniality project, Africanisation and Reformation, through literature study, the article calls for the decoloniality of faith in an effort to craft a vision for a non-racial society. This vision not only takes the importance of the redeeming memories of the 500 years of Reformation seriously, but also the notion of Africanisation and, in particular, the use of the African value systems in shaping and reconstructing a non-racial South Africa. This article taps into the resourcefulness of the Reformed faith in South Africa, as articulated in the theologies of Snyman, Tshaka and Botha, and applies them to South African discourses of decoloniality.

\section{Introduction}

By the rivers of Babylon, there we sat and wept, when we remembered Zion. On the willows there we hung up our lyres. For there our captors required of us songs, and our tormentors, mirth, saying, 'Sing us one of the songs of Zion!' How shall we sing the Lord's song in a foreign land? (Ps 137:1-4; Sproul 2005:859)

South Africa is a nation shackled by the chains of coloniality and apartheid. According to Theuns (2017:1-2), 'South Africa is suffering from many ailments and some of the most difficult of these to address are racism, xenophobia, sexism and economic inequality'. Colonial and apartheid hangovers, including racial stereotypes across different races, are still prevalent in our communities, both in public and private spaces. In their research, 'Whiteness, racism, and Afrikaner identity in the post-Apartheid South Africa', Verwey and Quayle (2012:552) refer to 'backstage talk of white, middle-class Afrikaners about blacks'. According to these researchers, this kind of talk is usually reserved for fellow whites or Afrikaners only. Backstage talk allows people of different races to talk badly about other races, based on stereotypes. Granted, backstage talk is not only limited to white people but takes place among black people as well. These conversations are often characterised by growing polarisation between 'us' and 'them', the consequence which is captured by Vorster (2017) as follows:

Usually 'us' are then clothed in a cloud of uniqueness and 'them' in a cloud of otherness. 'Us' forms the in-group and 'them' the out group. This demarcation is then followed by idolising the 'us' and demonising the 'them'. (p. 67)

Ngugi wa Thiong'o (1986:4-5) traces ailments such as coloniality, white supremacy and racism among others back to the division of Africa in 1884 when the capitalist powers of Europe sat in Berlin and carved an entire continent with a multiplicity of peoples, cultures and languages into different colonies. The continuity of the colonial discourse in the postcolonial and post-apartheid South Africa, however, calls for a decoloniality project (NdlovuGatsheni 2013:10). The decoloniality discourse occupies a prominent position in the public square. Its agenda covers all spheres of life - social, economic, political and religious. In his research, Ndlovu-Gatsheni (2013:11) concluded that institutions of learning and churches are sites for reproduction of coloniality; hence, we cannot exclude them when discussing issues of decoloniality. 
The decoloniality project has given birth, in the space of three years (2015-2017), to fallist movements such as \#RhodesMustFall (Mashau \& Mangoedi 2015:1), \#FeesMustFall (Naicker 2016; Nel 2017:201), \#OutsourcingMustFall (Luckett \& Mzobe 2016), \#SaveSouthAfrica, \#RacismMustFall, \#EnoughIsEnough and \#BlackMonday, among others. Although the social movements cited above are broadly concerned with the decoloniality project, the \#RhodesMustFall, \#RacismMustFall and \#BlackMonday movements are more related to issues of racial hangovers and undertones that exist in our private and public spaces today.

All of the above-mentioned movements have created a feeling of \#EnoughIsEnough among South Africans. The country has reached the same level of frustration as experienced by the Jews in Psalm 137, cited in the introductory quote, who refused to sing the Lord's song that was demanded by their captors. South African racial tensions have reached a level of proportion where citizens are starting to refuse to sing the song of 'reconciliation' as part of the nation-building project. The destruction of statues and defacement of others during \#RhodesMustFall, and the burning of the current national flag by some participants during \#BlackMonday, a protest held on 30 October 2017 in protest against the killings of white farmers, can be cited as two cases to this end. In his assessment of the current situation in South Africa, Vorster (2017:75) correctly concluded that the country is at a tipping point and that issues of racial reconciliation require more urgent attention than before.

This article seeks to locate the discussion around racial tensions and reconciliation in the post-colonial and postapartheid South Africa, particularly within the decolonial discourse. Subsequently, the article continues to probe the issue of decoloniality, Africanisation and Reformation, by working through the contributions of three African and Reformed scholars on the same issues, namely Profs. G.F. Snyman, N.A. Botha and R.S. Tshaka. As a biblical scholar, Snyman looks at the issues under discussion from a biblical scholarly perspective, whereas Tshaka takes the angle of practical theology. In the writings of Botha, who took the missiological angle, issues of race and reconciliation are addressed indirectly, without locating them directly to the decolonial project and Africanisation in particular. Building on the contributions of these three African theologians, this study will be concluded by efforts to tie together decoloniality, Africanisation and Reformation in proposing a vision towards a non-racial South Africa. My interest in this research is informed and shaped by three dynamics. Firstly, while being conscious and aware of other Christian traditions and practices, my personal journey of faith as an African Christian, missionary practitioner and missiologist has been formed and shaped by the Reformed faith (Calvinist tradition). Secondly, this tradition has a history which is tainted by its support of apartheid (see Kuperus 2011; Mashau 2014; Van Wyk 2005). Thirdly, as this tradition celebrates 500 years of Reformation this year (2017), it is critical to reflect on the potential contribution it can make towards a vision for a nonracial society today.

\section{Locating decoloniality in the South African public discourse Decoloniality: Whose agenda is it?}

The word decoloniality has become a buzzword in our private and public spaces. Decoloniality is receiving serious attention among academics in the world, particularly in the global south (see Dei 2018; Mignolo 2009; Morreira 2017; Ndlovu 2014), and it always runs the risk of being an elitist project. For this project to succeed, it has to be unshackled from the chains of academic scholars and allow voices of those in the margins of our communities to be heard. In presenting 'decoloniality as the future of Africa', NdlovuGatsheni (2015:485) places a non-optional imperative on all (South) Africans to engage on issues of decoloniality without failure and this is captured as follows:

What Africans must be vigilant against is the trap of ending up normalising and universalising coloniality as a natural state of the world. It must be unmasked, resisted and destroyed because it produced a world order that can only be sustained through a combination of violence, deceit, hypocrisy and lies. (NdlovuGatsheni 2013:10)

Looking at current political trajectories in South Africa, it becomes clear that decoloniality is the word which is reverberating in the corridors of our universities, with student movements calling for the decolonisation of the curriculum. It is asserted that ' $[t]$ he impetus for a renewed interest in decolonising the university curriculum in South Africa is the student protests of 2015' (Le Grange 2016:1). However, some of the fallist movements cited in the introduction of this article teach us that decoloniality is simply not the project of the 'elitist', or 'black diamonds', and not even the 'clever blacks' (black academics). Rather, it is a grassroots movement that has seen the mobilisation of South Africans across racial divides to stand side by side in a call for a decolonial and non-racial South Africa.

If the vision for a non-racial South Africa is to be realised, there is need for an open conversation between the coloniser and the ones colonised, something which is missing in our public square where it is almost difficult to talk about race issues without evoking the 'us' and 'them' divides. Speaking of decoloniality from a broader context, Ndlovu-Gatsheni (2015:485) calls for imperialist countries to undertake 'a deimperialisation movement by re-examining their own imperialist histories and the harmful impacts those have had on the world', whereas Maldonado-Torres (2011:7) encourages South-to-South encounters and dialogues in order to enrich the 'decolonial turn' project. These conversations are needed because people from the South share common colonial experiences. It is therefore mutually beneficial to reflect on those experiences, rethinking epistemologies and liberating praxes that can bring real transformation in their communities.

The list of stakeholders in the decolonial project will not be complete if the voice of faith-based communities is not 
added in the entire discourse. Churches in South Africa, especially Reformed churches, are guilty of perpetuating or supporting policies of racial discrimination in the past, and therefore, it is critical for same churches to take an active role in creating a non-racial society. Churches are, in this instance, called to serve as transforming agents that promote social cohesion (Mashau 2014:10, Mashau \& Mangoedi 2015:8). It is asserted that: "The church in South Africa must return to helping people confront and address deep-seated racist beliefs and practices and take the lead to welcome and assist strangers' (Pillay 2017:11).

\section{Decoloniality: A question of definition}

Building on the works of decolonial scholars like Nelson Maldonado-Torres and Walter D Mignolo, NdlovuGatsheni (2015:485) introduces and defines decoloniality as an 'epistemological and political movement; one which speaks to the deepening and widening of decolonization movements in those spaces that experienced the slave trade, imperialism, colonialism, apartheid, neo-colonialism, and underdevelopment' (p. 485). I partially agree with the definition provided which refers to decoloniality project as a political movement. The fallist movements, which mobilised active citizenry beyond political binaries and affiliations, teach us that decoloniality is also a social movement. Decoloniality is not just a political tool for resistance, but also a social movement that creates space for black people to redefine their identities and reaffirm their humanness as black and African in their very social locations (see Dei 2018:120).

According to Ndlovu-Gatsheni $(2015: 489,490),{ }^{\prime}[d]$ ecoloniality is premised on three concepts/unit of analysis'. These three concepts are coloniality of power (which is both political and economic), coloniality of knowledge and coloniality of being. In addition, and for the purposes of this article and our future engagement as church people, I want to propose the fourth concept or unit of analysis, which is coloniality of faith. The marriage between the empire and mission in the history of the church prompts me to propose this concept. It involves our South African history, where some of our churches, like the Dutch Reformed Church, supported apartheid directly. We can, therefore, define decoloniality, not only as a political, economic (exploitation of labour and material resources to benefit colonial powers), educational and social project, but also as a faith project. We can do so in the spirit of Psalm 137, where the Israelites wept and prayed bitterly, looking forward to their redemption and vengeance over their captors. According to Psalm 137, the Israelites were not only despondent to a point of refusing to sing the song of Zion to their enemies; they were also discontented with the manner in which their captors and tormentors mistreated them.

\section{Unmasking the hangovers and evil of coloniality}

According to Ndlovu-Gatsheni (2015):

[d] ecoloniality is born out of a realisation that ours is an asymmetrical world order that is sustained not only by colonial matrices of power but also by pedagogies and epistemologies of equilibrium that continue to produce alienated Africans who are socialised into hating the Africa that produced them, and liking the Europe and America that rejects them. (p. 489)

A closer analysis of the above quotation by Ndlovu-Gatsheni unreservedly unmasks the evil of coloniality. Firstly, it speaks against the notion of 'white supremacy', which was the racial undertone that accompanied colonial matrices of power when European powers conquered Africa with their imperialistic agenda. Issues of 'whiteness', 'racism' and 'white privilege' are components of 'white supremacy' and are associated with the political power during the colonial and apartheid regimes. Secondly, it introduces the issue of racism and racial undertones that define the relationship between black people and white people. Thirdly, the quote by Ndlovu-Gatsheni introduces the notion of 'blackness' and 'a feeling of inferiority', as introduced by the likes of Franz Fanon when defining the relationship between the two races in his book, Black Skin, White Masks (Fanon 1952). Accordingly, some black people always try to measure themselves against their white counterparts, using them as a measure of success. Ndlovu-Gatsheni talks about Africans who like Europe and America, as in admiring them, looking up to them or using them as their models.

Fourthly, the continual use of 'Europe and America' as a model and use of English as a dominant language in our education system speaks to the marginalisation of the indigenous knowledge system. Ndlovu-Gatsheni speaks about 'pedagogies and epistemologies of equilibrium' as a knowledge system that enhances the colonial matrices of power by glorifying Western scholarship over indigenous knowledge systems. Speaking in the context of Kenya, Ngugi wa Thiong'o (1986:11) bemoans how English, under colonial rule, became a dominant language of education and how that eroded the indigenous culture and knowledge system and subjected black folks to mental control by the coloniser. The colonisation of a black mind is a dehumanising activity with devastating and disempowering outcomes at the end. It is concluded that: 'There is nothing more psychologically damaging, religio-culturally disengaging and destructive to successful social, political and economic development and human progress than this brainwashing or mind control' (Kaunda 2015:78-79).

Lastly, the quote by Ndlovu-Gatsheni cited above speaks about the continued 'dehumanisation of blacks'. Black people are stereotyped as being lazy, crooks, violent, rapists, illiterate and half-human or less human. This does not only perpetuate an inferiority complex among black people, but is intentionally designed to knock off their self-confidence (Mpofu 2013:109). For example, the Penny Sparrow racial rant case can be cited to illustrate this type of hangover of racial tensions in the country. In her Facebook post (posted on 01 April 2016 at 12:45), Penny Sparrow referred to black people as monkeys and illiterate. By levelling damning accusations against black people, Penny Sparrow becomes not only a representative of the apartheid past but someone who represents the mentality of white domination and colonial history. 
The unfortunate part is that these hangovers are not only prevalent in the public square, but also in church circles. While we note with disappointment that racial segregation was supported by reformed churches like the Dutch Reformed Church during the apartheid era, racial undertones continue to manifest in church circles from time to time. Pastor Andrew Olivier of Rivers Church in Sandton caused a racial stir that set social media ablaze with accusations of him being a racist. In his defence of white money, Olivier touched on the issue of white privilege, especially in the apartheid era, when he said:

We took nothing from no one. Maybe the law favoured us, but we worked, and I am still working. And when you tell me I need to share my wealth, what are you suggesting? Are you suggesting I give away some of it? Are you giving any of yours away? Excuse me? (See Mail \& Guardian, 28 October 2017)

This and other related stories illustrate that, while colonialism as a form of political subjugation is dead, coloniality continues to raise its ugly head. The colonial power matrices still heavily influence our private and public discourses daily; hence the need for a 'decoloniality turn' today. This project will allow Africans space not only to resist the dominance of Western hegemony in all spheres of life but also to use African and decolonial epistemologies in redefining the identity and future of African people. In the quest to reframe blackness for decolonial politics, Dei (2018:120) emphatically calls for reflections that seek to affirm blackness by resisting the dominant perspective of the coloniser. The rich heritage of indigenous knowledge systems should be given space to thrive by tapping into the black lived experience, languages and rich cultures without having to justify their very existence and presence in the public square.

\section{Decoloniality and reformation John Calvin as a decolonial scholar}

Reading John Calvin from the lenses of decoloniality today, one can easily conclude that he was a decolonial scholar of note. Looking closely into the manner in which Calvin dealt with the question of slavery in his time, Kayayan (2013) elucidates:

Looking at what Calvin wrote on slavery, in particular at his aversion, vehemently expressed, to a practice which he not only sees as obsolete but which he also deems unthinkable to reinstate (... which cannot be done amidst the humanity which we keep amongst ourselves ...), one can reasonably assume that he would have approached the civil authorities of his own time in the way indicated in his sermon on Ephesians 6 in order to counter the reappearance of this practice, had he directly taken cognisance of it. (p. 13)

\section{South African Calvinists, coloniality and apartheid}

The association of some of our reformed churches in South Africa, in particular the Dutch Reformed Church, who were open about their support for the racial segregation policy of apartheid, leaves a bitter taste on one's tongue when talking about South African Calvinism, especially in the area of race relations. Accordingly, the Afrikaners were considered superior to the 'obviously damned' Bantu and other indigenous peoples such as the Khoi and the San. This kind of history teaches us how much the Scriptures can be abused to oppress others and keep racial divisions intact. As we celebrate 500 years of Reformation, we should, collectively, not only be ashamed of this part of our history, but also be able to confess our participation, in order to move forward and forge the spirit of reconciliation among different races. It is shocking how much the church today is failing to take the lead as far as matters of reconciliation are concerned.

\section{South African Calvinists and decoloniality}

Historically, there are antecedents of the reformed faith who stood against apartheid and racial segregation policies in the past, like Beyers Naude, Allan Boesak and JM Vorster, among others. Building on the voices of these personalities, there are to date many writings from South African Calvinists that address the issues of decoloniality. These are writings that address sensitive matters, including 'whiteness', 'blackness', 'white superiority', 'black inferiority and lowself-esteem', 'white privilege', 'black privilege', 'racism' and reconciliation. These Calvinists must be applauded for their bravery and frankness in dealing with these matters. For the purpose of this paper, I will refer to the writing of Profs. Gerrie Snyman, Nico Botha and Rothney Tshaka. Prof. Gerrie Snyman comes from the Reformed Churches in South Africa (GKSA/RCSA), while the other two belong to the Uniting Reformed Churches of Southern Africa (more of a splinter group from the Dutch Reformed Church). The experience of the two, as people who were part of the Dutch Reformed Church before 1994, will surely add more value to our decoloniality discourse, and in particular issues of race and reconciliation.

\section{Decoloniality and the reformed faith: Drinking from our own wells Prof. Gerrie F. Snyman}

Speaking from a perspective of being white, Afrikaans and reformed (Reformed Churches in South Africa) as far as faith persuasion is concerned, Snyman employs a hermeneutic of vulnerability in addressing issues of decoloniality, coloniality, racism and related matters. His hermeneutic of vulnerability is paradoxically placed. On the one hand, Snyman is aware of his privileged position as a white man, and on the other, he is aware of the baggage of coloniality and apartheid that he carries by default of being white. On decoloniality, Africanisation and Reformation, Snyman highlights the following.

Decoloniality is a project that African churches should embrace and attend to as a matter of urgency. According to Snyman (2015:270), Colonial discourse persists after apartheid. He cites two reasons for his standpoint, namely, (1) In 1991, the RCSA-synod failed to make formal presentations to the Truth and Reconciliation Commission on the basis that they 
have been critical enough about apartheid for the past 31 years, while in essence the majority of their members actively participated in the politics of the day. The participation of some of their members in national politics and the setting up of racially biased and offensive laws is a serious point of concern, according to him. (2) He critically rejects the colonial missionary language. He decries the use of the word 'dark' with particular reference to Africa as used by PJ (Flip) Buys in his article that appeared in the September 2010 issue of Die Kerkblad under the title, 'The regenerating power of the gospel in dark Africa'. (Die vernuwende krag van die evangelie in donker Afrika) (see Snyman 2015:271). It is quite strange that a missionary like PJ Buys, as cited by Snyman above, would still refer to Africa as a dark continent in such a time as this. The use of the phrase 'dark continent' does not only have colonial undertones but also refers to Africa as a continent which is still backward and unchristian (associated with evil as if there is nothing good that can come out of Africa), especially when used by a white missionary to refer to the black context. The issue of whiteness and white supremacy is a reality in the post-apartheid South African context (Snyman 2011:464). This, according to Snyman, is an issue of identity and culture, which is defined against the identity and culture of other races, and in particular that of Africans. Discussing the issue of whiteness and apartheid, Snyman (2014) maintains:

White identity is apparently still the master signifier despite its loss of political power. What sets it apart from Africanness is its colonial past that is regarded as a history of exploitation, humiliation and disempowerment. Indigenous Africans and the colonists (whites) who settled on African soil do not share a common culture, in spite of sharing the same geographical space and a common destiny. (p. 403)

Indeed, the majority of white people conveniently refer to themselves as Africans when it suits them, but in the main, they associate themselves with Europe, and therefore refer to themselves as Western. According to Snyman, nobody wants to take blame for having participated in the practice of apartheid. They choose to ignore those memories. In driving this point home, Snyman (2014) reflects on memory and personal experience as follows:

Official public memory is shaped by powerful elites, fed by the personal memories of its respective members in the antiapartheid struggle. However, the personal memory of whiteness is not one of practicing apartheid. No one wants to remember how he or she enforced racism in the personal sphere. (p. 403)

Calling upon white South Africans to embrace decoloniality, Snyman concludes his discussion on whiteness and the failing memory of many as follows: 'But in some way it should be brought into our memories' (p. 403).

Without direct mention of the 'homogeneous ministry' praxis within the Reformed Churches in South Africa (GKSA/RCSA), Snyman warns that 'keeping people within racial categories denies a reality of people moving across racial borders to form multiple belongings' (2014:403). Homogeneous ministry is not wrong in itself, but there is everything wrong with it when it is used intentionally to exclude other nationalities from joining.
I often hear white Afrikaans brothers using 'language' and 'culture' as an excuse as to why they can only minister to their people (fellow white Afrikaans). Some will openly mention that they cannot use 'the enemy's language', with particular reference to the aftermath of the Anglo-Boer War. But, when it is convenient for them, black people are either expected to speak in Afrikaans or use English as if it is their mother tongue.

In his analysis of the South African context, Snyman accedes that race issues are deeply entrenched in our communities, even church communities for that matter. These issues have coloured our judgements over our understanding of church (ecclesiology) and the practice thereof. Snyman (2014) highlights this as follows:

With Christianity entrapped in racialized discourse, always accompanied by symbolism of colour, it seems as if our memory has engraved racial divisions. Even our attempts to be non-racial turn out to be the reverse. (p. 409)

To me, this is most relevant in any debate on church unity. We still speak very much of 'us' and 'them', and in some instances speak past each other, because the RCSA is not our church together.

In proposing a way forward, Snyman (2014:421) encourages: 'white people [and black people] to engage in a journey [together] where they are able to critically analyse the power of whiteness within whiteness itself'. In addition, he pointed out that ' $[w]$ hiteness needs to work through its Christian heritage that is associated with imperialism, conquest and colonialism that fed racism' (p. 421). If the decoloniality turn is to succeed, Snyman called for Reformation within the Western theological epistemologies and praxes around issues of whiteness and racism. He also called white people to embrace Africanisation in the process.

\section{Prof. Nico Botha}

Prof. Nico Botha, an African from the Uniting Reformed Church of Southern Africa (URCSA), a splinter group from the Dutch Reformed Church, is another voice that has embraced the notion of decoloniality in his writings. In his article, 'Living at the edge of empire: can Christianity prevail and be effective? A theological response to the historical struggle between empire and Christianity', Botha (2011) highlights the following: (1) The hermeneutic of dominance is unacceptable. (2) Christianity cannot be in the same bed with empire. It inhibits the prophetic role of the church. He questions the wisdom of turning Christianity into a state religion during the times of Constantine. 'There was indeed something incongruent between early Christianity and the Roman Empire, with Christianity becoming the official religion in a short span of 300 years' (p. 2). (3) The prophetic voice of the church should not be diluted by succumbing to the exploits of the empire in amassing power and control, as we have witnessed in the relationship between the Dutch Reformed Church and the apartheid regime. According to Botha, 'Christianity is also more than a belief: it generates a "culture" of justice, equality and loving service, a set of 
convictions and ways of life' (p. 3). (4) Christianity, according to Botha, has a transforming influence and the ability to be on the side of the oppressed. It has a calling to be the 'salt of the earth' and the 'light to the world' (p. 3). (5) The marriage between colonial powers and the church, in particular on the mission front, was a very bad move on the side of the church. (6) Christianity can be saved from this entanglement with Jesus Christ at the centre of the church's proclamation. Jesus is projected as one who stood against the oppressive structures of his time and also provided healing to those afflicted by all forms of sickness. Jesus Christ is the great Unifier of humankind; and therefore, we should be able to live side by side as family and friends. (7) Healing, according to Botha, is possible, even on the front of racial atrocities experienced during colonial and apartheid South Africa. In his thinking, inspired by the redeeming memories of Reformation, and in particular the sola fide and solo Christos, we see something of the arrays of the theology of hope. (8) Botha, however, laments the betrayal of the poor people with the provision of cheap reconciliation that was hastily done without taking issues of restitution into consideration. Accordingly, true reconciliation has to take matters of justice seriously. Sharing in redressing the inequalities of the past is critical for him. The foregoing has direct implications for issues around decoloniality, Africanisation and Reformation. The church should always be seen as an agent of transformation that seeks to confront, interrogate and engage prophetically powers that be, including issues of racism, forgiveness and reconciliation.

\section{Prof. Rothney S. Tshaka}

Prof. Rothney Tshaka $(2007 ; 2014 ; 2015)$, an African from the Uniting Reformed Churches of Southern Africa (UCRSA), adds a special voice, in that he deals more with the identity of African Reformed Christians who have to define themselves outside the scope of the Western Mind. In his writings, the following issues, with direct bearing on decoloniality and the reformed faith, are highlighted: (1) African Reformed Christians have no obligation to mimic and replicate European Reformed Christians in living out their reformed faith. He asserts that 'African Reformed Christians are therefore charged with a monumental task of correcting the misconceptions that have befuddled not only the Western mind but have mystified even the colonized African mind' (Tshaka 2007:546). (2) In his approach, Tshaka uses the hermeneutic of black liberation theology, not only to unmask the influence of colonial thinking in post-apartheid South Africa but also to engage issues of blackness, race, discrimination and liberation, among others. Tshaka and Makofane (2010) argue for the continued use of this hermeneutic to allow black people to define their story. (3) Tshaka (2015) criticises the dependency syndrome which was brought about by the white benevolence of the Dutch Reformed Church as a silencing tool to prevent black people from lifting their voices against the injustices of the white people. We also see this within our Reformed Churches in South Africa: those who are dependent on 'white money' will always sing for their bread. (4) He calls for a paradigm shift in our ecclesiology - the discourse around mother-daughter churches is very prominent in his discussions, and he objects to it. (5) He also questions the dominance of Reformed white theology. To date, you still have the compartmentalisation of theological training across racial lines. It is rare to find white Afrikaners who do their training with the intention of serving in African churches, and the same applies to Africans.

We can safely conclude that Tshaka's views on decoloniality, Africanisation and Reformation is very liberating as far as African Reformed Christians are concerned. He encourages black Africans to rethink and redefine their identity, epistemologies and praxes thereof. The African Reformed Christians will be truly reformed and African when they rid themselves of the shackles of the chains of coloniality by reflecting, in doing theology, on the shared experience of the black lived life. In this way, decoloniality, Africanisation and reformation which are domesticated are inevitable.

\section{Decoloniality, Africanisation or reformation? Reimagining the future}

Drawing from the voices of Snyman, Tshaka and Botha, it is clear that Africanisation and Reformation belong together when addressing issues around the decoloniality discourse, and in particular the decolonisation of faith, to address race and reconciliation in the post-colonial and post-apartheid South Africa. This section is aimed at mapping a way forward in terms of how best South Africa can move forward as a racially united nation where we experience true reconciliation by tapping into the resourcefulness of concepts such as decoloniality, Africanisation and Reformation.

According to the decolonial scholar, Frantz Fanon, every generation must discover its mission and fulfil it. It is upon this generation, in line with the mandatory generational responsibility expressed by Fanon, to take up the challenge of the decoloniality project and make Africa and the rest of the world a home for all who live in it.

On the question of whether we should choose between 'decoloniality' and 'Africanisation', it remains clear that the struggle of decoloniality is not divisive in nature. It is not necessarily an antithesis of coloniality but one that seeks to foster Afrocentric prescriptions to life in an uncompromising manner. African renaissance should remain at the heart of any decoloniality project. In addition, for us to understand issues raised, we should not shy away from engaging the black theology of liberation and discern from those voices from the margins as to how we should move forward in terms of racial reconciliation in this country.

There is need to liberate the reformed faith from colonial matrices of power; hence the call by many for the return of the Christian faith to Africa, a continent considered by many 
to be the heartland of this faith. We have to dispel the myth that Christianity is a Western religion and the Bible is a white man's book. The sola Scriptura principle of Reformation should be embraced by the African church as we wrestle with issues of racial reconciliation in our country.

With the call back to God and the call back to the Scriptures (the sola Scriptura principle of Reformation), the decoloniality project should help African Christians to reaffirm the equality of the entire human race and the rejection of any form of human oppression, whether it takes the form of white supremacy, racism, sexism or otherwise. This should include 'reverse racism on the side of blacks' as well.

Furthermore, African concepts of ubuntu should be embraced to enhance the communality of our human race and to advance true reconciliation and unity of our highly polarised rainbow nation. As all of humanity, irrespective of race, is created in the image of God (Imago Dei), we should treat one another as equals. According to Vorster (2010:210), the biblical concept of imago [D]ei, as used in the reformed tradition, is essential to any approach to humanness and human relationships. The image of God in others should be respected and cherished.

Racism, tribalism, xenophobia, homophobia and any form of segregation based on gender are social ills, which came because of $\sin$. There is need to be reconciled with God and then with one another. The Reformation memoir of 'total depravity' of man should encourage all fallen men and women to seek God's grace to overcome all racial challenges they encounter daily. There is, therefore, great need for the redeeming memoirs of Jesus Christ and his reconciling acts on the cross for fallen humanity to be saved and be reconciled with one another as well.

There is need to rediscover a missional ecclesiology that defines the church as an instrument in the mission of God in this world. The church is a community reconciled with God to become reconciliation agents. It is, however, very unfortunate that churches have not progressed much in terms of becoming the light and salt of the world. Churches are failing in their calling to serve as God's witnessing community in this age.

There is need for South Africans across racial divides, and reformed churches in particular, to make more efforts to worship together and intentionally create more multiracial communities to celebrate our reconciliation with God and with one another. This community should be able to celebrate their reconciliation with God and with one another by hosting communal Holy Communion meetings.

There is need for the theology of hope and accompaniment. This is anchored on the 'faith alone' principle of Reformation. Reconciliation is a process, which can only happen when we journey together as God's people from diverse race groups. We should emphasise more of our identity in Christ than our diversity. We belong to one body of Christ and therefore should always treat one another that way.

\section{Conclusion}

Should South Africans, and in particular reformed Christians, sing the song of Zion regarding race and reconciliation in a country that is racially polarised? Instead of acting like the Israelites who sat down, cried and even, incorrectly, started praying for their enemies to receive vengeance and be punished for tormenting them, South Africans should never stop singing our song. All the hashtags and fallist movements cited in this article are a wake-up call for us to start working together in fostering true racial reconciliation in the post-colonial and postapartheid South Africa, which is still suffering from colonial and apartheid hangovers. Decoloniality, Africanisation and Reformation, in this article, teach us that reconciliation is God's song which must be sung by all. We should not allow pain, suffering, racial stereotypes and prejudices in some sections of our communities to steal our song. South Africa should join all Christians worldwide in calling for peace, forgiveness and true reconciliation across racial divides.

This article drew on the redeeming memoirs of the 500 years of Reformation. In particular, it tapped into the resourcefulness of the Reformed faith in South Africa, as articulated in the theologies of Snyman, Tshaka and Botha, and applied their ideas to our decoloniality discourses. This helped us to realise the importance of decolonising the Christian faith from the colonial matrices of power and the influence of the empire in the praxis of that faith.

The decoloniality of faith will help us, not only to appreciate the richness of the Reformed faith in promoting the imago Dei in all humanity and thereby fostering true unity across racial divides but also to embrace the process of Africanisation. We should utilise the rich language present in African value systems on issues of forgiveness, reconciliation and reconstruction in building a non-racial society, and in particular we should use and apply the notion of ubuntu in our theologising. We should be able to come up with a vision that will unite all South Africans. This vision should include, among others, the ability to acknowledge our contribution in dividing our community (directly or indirectly), repentance, confession, forgiveness, reconciliation, reconstruction and peace building. Embracing African concepts like ubuntu in our communities will assist us to move forward and reconcile our people. This, unfortunately, is not going to be a once-off exercise but a continuous journey that will require courage and perseverance in pursuit of a liberating decoloniality of faith.

\section{Acknowledgements Competing interests}

The author declares that he has no financial or personal relationships which may have inappropriately influenced him in writing this article. 


\section{References}

Botha, N., 2011, 'Living at the edge of empire: Can Christianity prevail and be effective? A theological response to the historical struggle between empire and Christianity', Studia Historiae Ecclesiasticae 2011(37 Suppl), 133-155.

Dei, G.J.S., 2018, “'Black like me”: Reframing blackness for decolonial politics', Educationa Studies 54(2), 117-142. https://doi.org/10.1080/00131946.2018.1427586

Fanon, F., 1952, Black skin, white masks, Grove Press, New York.

Kaunda, C.J., 2015, 'The denial of African agency: A decolonial theological turn', Black Theology 13(1), 73-92. https://doi.org/10.1179/1476994815Z.00000000048

Kayayan, E., 2013, 'Corrigendum: Calvin on slavery: Providence and social ethics in the 16th century', Koers - Bulletin for Christian Scholarship 78(2), Art. \#2119, 1-12. https://doi.org/10.4102/koers.v78i2.2119-1

Kuperus, T., 2011, 'The political role and democratic contribution of churches in postapartheid South Africa', Journal of Church and State. https://doi.org/10.1093/jcs/ csr030

Le Grange, L., 2016, 'Decolonising the university curriculum', South African Journal of Higher Education 30(2), 1-12. https://doi.org/10.20853/30-2-709

Luckett, T. \& Mzobe, D., 2016, '\#OutsourcingMustFall: The role of workers in the 2015 protest wave at South African universities', Global Labour Journal 7(1), 94-99. protest wave at South African universitidorg/10.15173/glj.v7i1.2839

Maldonado-Torres, N., 2011, 'Thinking through the decolonial turn: Post-continental interventions in theory, philosophy, and critique - An introduction' Transmodernity: Journal of Peripheral Cultural Production of the Luso-Hispanic World 1(2), 1-15.

Mashau, T.D., 2014, 'Reimagining mission in the public square: Engaging hills and valleys in the African City of Tshwane', HTS Teologiese Studies/Theological Studies 70(3). Art. \#2774, 1-11. https://doi.org/10.4102/hts.v70i3.2774

Mashau, T.D. \& Mangoedi, L., 2015, 'Faith communities, social exclusion, homelessness and disability: Transforming the margins in the city of Tshwane', HTS Teologiese Studies/Theological Studies 71(3), Art. \#3088, 1-9. https://doi.org/10.4102/hts. v71i3.3088

Mignolo, W.D., 2009, 'Epistemic disobedience, independent thought and decolonia freedom', Theory, Culture \& Society (SAGE, Los Angeles, London, New Delhi, and Singapore) 26(7-8), 159-181. https://doi.org/10.1177/0263276409349275

Morreira, S., 2017, 'Steps towards decolonial higher education in Southern Africa? Epistemic disobedience in the humanities', Journal of Asian and African Studies 52(3), 287-301. https://doi.org/10.1177/0021909615577499

Mpofu, W.J., 2013, 'Coloniality in the scramble for African knowledge: A decolonia political perspective', Africanus 43(2), 105-117. https://doi.org/10.25159/0304$615 \mathrm{X} / 2305$

Naicker, C., 2016, 'From Marikana to \#feesmustfall: The praxis of popular politics in South Africa', Urbanisation 1(1), 53-61. https://doi.org/10.1177/2455747 116640434

Ndlovu, M., 2014, 'Why indigenous knowledges in the 21st century? A decolonial turn', Yesterday \& Today 11, 84-98.

Ndlovu-Gatsheni, S.J., 2013, 'Why decoloniality in the 21st century?', The Thinker for Thought Leaders 48, 10-15.
Ndlovu-Gatsheni, S.J., 2015, 'Decoloniality as the future of Africa', History Compass 13(10), 485-496. https://doi.org/10.1111/hic3.12264

Nel, R.W., 2017, '\#Feesmustfall from Belhar to Accra: A postcolonial terrain of struggle for economic justice?', in J.A. du Rand, J.M. Vorster \& N. Vorster (eds.) Togetherness in South Africa, pp. 201-228, AOSIS, Cape Town. https://doi. org/10.4102/aosis.2017.tsa49.08

Ngugi wa Thiong'o., 1986, Decolonising the mind: The politics of language in African literature, Heinemann, Nairobi.

Pillay, J., 2017, "Racism and xenophobia: The role of the church in South Africa", in "Ecodomy - Life in its fullness"', Verbum et Ecclesia 38(3 Suppl 1), a1655. https:// doi.org/10.4102/ve.v38i3.1655

Snyman, F.G., 2008, 'Is it not sufficient to be a human being? Memory, Christianity and white identity in Africa', Religion \& Theology 15, 395-426.

Snyman, F.G., 2011, “'Looking into black eyes and feel the embarrassment." A selected and selective reading of the Africana Bible', OTE 24(2), 464-491.

Snyman, F.G., 2015, 'Responding to the decolonial turn: Epistemic vulnerability', Missionalia 43(3), 266-291. https://doi.org/10.7832/43-3-77

Sproul, R.C., 2005, 'Psalm 137:1-4', in The reformation study bible, Ligonier Ministries, Orlando, FL.

Theuns, E., 2017, 'The historical and recent socio-political context for considering racism and related concepts in South Africa', in J.A. du Rand, J.M. Vorster \& $\mathrm{N}$. Vorster (eds.), Togetherness in South Africa, pp. 1-28, AOSIS, Cape Town. https://doi.org/10.4102/aosis.2017.tsa49.01

Tshaka, R.S., 2007, 'African, you are on your own! The need for African reformed Christians to seriously engage their Africanity in their reformed theological reflections', Scriptura $96,533-548$.

Tshaka, R.S., 2014, 'On being African and reformed? Towards an African reformed theology enthused by an interlocution of those on the margins of society', HTS Teologiese Studies/Theological Studies 70(1), Art. \#2070, 1-7. https://doi. org/10.4102/hts.v70i1.2070

Tshaka, R.S., 2015, 'The black church as the womb of black liberation theology? Why the Uniting Reformed Church in Southern Africa (URCSA) is not a genuine black church?', HTS Teologiese Studies/Theological Studies 71(3), Art. \#2800, 1-10. https://doi.org/10.4102/hts.v71i3.2800

Tshaka, R.S. \& Makofane, M.K., 2010, 'The continued relevance of black liberation theology for democratic South Africa today', Scriptura 105, 532-546. https://doi. org/10.7833/105-0-155

Van Wyk, I.W.C., 2005, 'The political responsibility of the church: On the necessity and boundaries of the theory of the two kingdoms', HTS Teologiese Studies/ Theological Studies 61(3), 647-682. https://doi.org/10.4102/hts.v61i3.457

Verwey, C. \& Quayle, M., 2012, 'Whiteness, racism, and Afrikaner identity in postapartheid South Africa', African Affairs 111(445), 551-575. https://doi.org/ 10.1093/afraf/ads056

Vorster, J.M., 2010, 'Calvin and human dignity', In die Skriflig 44(Suppl 3), 197-213. https://doi.org/10.4102/ids.v44i0.189

Vorster, J.M., 2017, 'Racism in South Africa: Are we at a tipping point?', in J.A. du Rand J.M. Vorster \& N. Vorster (eds.), Togetherness in South Africa, pp. 59-78, AOSIS Cape Town. https://doi.org/10.4102/aosis.2017.tsa49.03 